\title{
Filipperbrevet 3,2-11 og det "radikalt" ny Paulusperspektiv
}

\author{
(eller "Paul Within Judaism”) \\ Adjunkt, ph.d. \\ Jacob P.B. Mortensen, Aarhus Universitet
}

\begin{abstract}
In this article, I explain the main concepts and positions within the so-called radical new perspective on Paul. I also turn to Philippians 3:2-11 in order to apply "radical" insights to Philippians. Even though radical scholars have not yet produced a complete interpretation of Philippians, several among them have turned to Philippians 3-passage in order to cope with Paul's apparent vilification of Jews as dogs and his description of his "former" life in Judaism. The radical insights, which flow from these approaches, may not provide a completely new understanding of the letter to the Philippians, but they do compel us to rethink certain traditional perceptions of the Philippian situation and Paul's self-understanding.
\end{abstract}

Keywords: Paul within Judaism - Philippians - Jews/Jewish Christians/Judaizers as dogs - Reversal of invective - The Philippian situation - Paul's self-understanding.

\section{Introduktion}

I denne artikel introducerer og applicerer jeg indsigter fra det såkaldt "radikalt" nye Paulusperspektiv (også kendt som "Paul Within Judaism") til Filipperbrevet. I den første del af artiklen introducerer jeg tre vigtige tematikker eller kendetegn, der definerer det radikalt nye perspektiv. I anden del af artiklen eksemplificerer og anvender jeg det radikalt nye perspektivs fortolkningsmæssige tilgang til Filipperbrevet. Afslutningsvis vurderer jeg de fortolkningsmæssige pointer i en overordnet forståelse af det paulinske missionsforetagende. 


\section{Det radikalt nye perspektiv - personer, positioner og tematikker}

For at forstå det radikalt nye perspektiv vil jeg indledningsvist aftegne nogle repræsentative forskningsmæssige positioner, der enten implicit eller eksplicit har skubbet det "nye" Paulusperspektiv videre i retning af det radikalt nye perspektiv eller "Paul Within Judaism." Nogle af de forskere, der tager del i denne "bevægelse," har enten åbent erklæret sig selv som værende "radikale forskere" og/eller har bidraget til bogen, Paul Within Judaism (2015). ${ }^{1}$ De artikler, der forekommer i Paul Within Judaism, er indtil videre det tætteste, der findes på en samlet præsentation af det radikalt nye perspektiv, men bogen kan ikke anses for at være et programskrift eller manifest.

Selvom præsentationen af det radikalt nye perspektiv her forekommer som en samlet størrelse, er det vigtigt at påpege, at dette ikke faktisk er tilfældet. Der findes ikke et samlet radikalt perspektiv med et sæt af hypoteser, som alle bidragydere tilslutter sig. Der findes en betydelig forskellighed i henseende til specifikke eksegetiske detaljer blandt de forskere, der bidrager til det radikale perspektiv, og disse forskelle skal - i al "fairness" - påpeges. Ikke desto mindre er det alligevel muligt at påpege særlige træk og pointer, der konvergerer mellem disse forskere, hvorved en form for konsensus (på visse punkter) forekommer. Og den betydeligste egenskab, der går igen hos alle disse forfattere, er deres ønske om at komme hinsides det nye Paulusperspektiv.

De tre vigtigste områder, der definerer det radikalt nye perspektiv, omhandler:

a) Konsekvenserne af det nye perspektiv.

b) En to-pagts teologi eller en Sonderweg fortolkning af Rom 11,26 ("og så skal hele Israel frelses").

c) Paulus, hedningernes apostel. ${ }^{2}$

1. Mark Nanos \& Magnus Zetterholm (red.), Paul Within Judaism: Restoring the First-Century Context to the Apostle (Minneapolis: Fortress Press 2015).

2. Spørgsmålet om en subjektiv eller objektiv genitiv i forståelsen af $\pi i ́ \sigma \tau 1 \zeta$

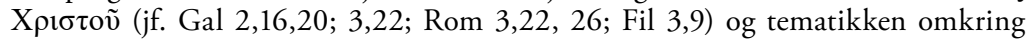
Guds $\delta ı \alpha \iota \sigma \sigma u ́ v \eta v$ er generelt set vigtig for alle radikale forskere. Dette spørgsmål udgør dog ikke i sig selv en radikal pointe eller tematik. Mange radikale forskere er enige med forskere fra det nye perspektiv, der hævder, at udtrykket skal forstås som betegnende "Kristi trofasthed" frem for en "tro på Kristus." I den forstand er Kristi trofasthed en kompakt og komprimeret forståelse af Kristi lydighed indtil døden, Kristi tjenestevillighed og selv-overgivelse i lydighed mod Gud. Denne forståelse af udtrykket pointerer, at Paulus var fuldt ud overbevist om, at Gud anså 
Jeg behandler disse tre punkter i det følgende, men i arbejdet med Filipperbrevet behandler jeg kun punkt a og c, da jeg ikke kommenterer på Romerbrevet 11,26 i denne artikel.

\section{Konsekvenserne af det nye perspektiv}

Det siger nærmest sig selv, at det radikalt nye perspektiv udvider og yderligere udfolder indsigterne fra det nye perspektiv, som det oprindeligt kom til udtryk i arbejdet fra E.P. Sanders, James Dunn, Heiki Räisänen og andre. ${ }^{3}$ Ifølge de radikale forskere er det nye perspektiv ikke nyt nok. E.P. Sanders begreb om "covenantal nomism" og den fuldt ud positive opfattelse af "Second Temple Judaism" må yderligere radikaliseres. Ifølge de radikale forskere findes der ingen spor af gerningsretfærdighed i teksterne fra det andet tempels periode, imod hvilke Paulus skulle advare. Derudover værdibestemmes eller vurderes den jødiske religion på Paulus' tid på ingen måde, og den sammenlignes ikke med kristendommen. Den kritik af jøderne/jødedommen, der findes i Paulus' breve, omhandler ifølge de radikale forskere hverken Israel, den jødiske religion, eller den almindeligt troende jøde på den tid. Derudover er der ingen "erstatning" (eng: supersessionism) af jødedommen med kristendommen. Konsekvensen af disse indsigter er, at der ofte findes et apologetisk element og forsvar i arbejdet med "Second Temple Judaism" hos de radikale forskere, der modstilles med "kristianiserende" tendenser og fortolkninger. Det fastholdes hårdnakket blandt de radikale forskere, at Paulus ikke skabte en ny religion (kristendommen), som han konverterede til. Paulus omvendte sig ikke fra jødedommen til kristendommen, men blev kaldet inden for jødedommen, og i sit virke forblev han inden for jødedommen (derfor: Paul Within Judaism). Derudover hævder de radikale forskere, at Paulus ikke blev en lov-fri apostel for hedningerne. Tværtimod hævder flere radikale forskere, at Paulus forblev en gudfrygtig, lovtro og ivrig jøde, selvom han fastholdt at hedningerne ikke skulle omskæres, når de kom til tro på den

Kristi trofasthed (indtil døden) som en gerning, hvormed Gud forligte dem (= hedningerne), der tidligere var hans fjender eller "ikke-hans-folk" med sig selv. (Jf. Richard Hays, The Faith of Jesus Christ: An Investigation of the Narrative Substructure of Galatians 3:1-4:11 (Chico: Scholars Press 1983); Sam K. Williams,

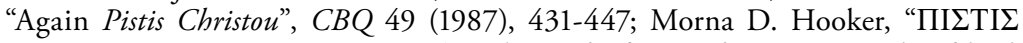
XPIITOY”, NTS 35 (1989), 321-342; The Faith of Jesus Christ: Exegetical, Biblical, and Theological Studies, red. Michael F. Bird \& Preston M. Sprinkle (Peabody: Hendrickson Publishers 2009.)

3. For en dansk introduktion til forfatterne og indsigterne i det nye perspektiv, jf. red. Troels Engberg-Pedersen, Den nye Paulus og hans betydning (København: Gyldendal 2003). 
jødiske messias. ${ }^{4}$ Nogle radikale forskere hævder ligefrem, at Paulus stadig fastholdt omskærelse for jøder.

\section{To-pagts teologi eller Sonderweg}

I spørgsmålet om en to-pagts teologi eller Sonderweg fortolkning af Rom 11,26, kan det være informativt at undersøge de forskningsmæssige forgængere for de radikale forskere. Disse forgængere er Franz Mussner, Krister Stendahl, John Gager, Lloyd Gaston og Stanley Stowers.

Franz Mussner er en forgænger til det radikalt nye perspektiv, fordi han var den første, der argumenterede for en Sonderweg forståelse af Rom 11,25-26, der omhandler den påstand, at når hedningerne er

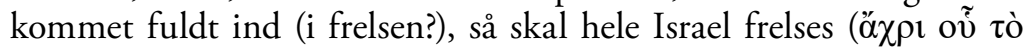

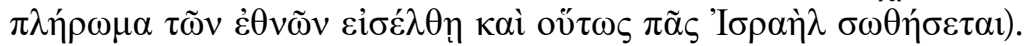
Mussner redegjorde for sin læsning af Romerbrevet i en bog fra 1979. ${ }^{5}$ Nogle forskere argumenterer for, at Sonderweg forståelsen af Romerbrevet også kan betegnes som en to-pagts teologi, men der er divergerende forståelser af, hvad dette begreb indeholder. Oprindeligvis argumenterede Mussner for, at Sonderweg forståelsen bestod i, at Israel ikke ville blive frelst før Kristi genkomst. Når Kristus kommer igen, vil Israel se messias stige ned fra himlen som den specifikt kristne messias, og når Israel derefter hører evangeliet blive forkyndt, vil de respondere på forkyndelsen og omvende sig til kristendommen. ${ }^{6}$ Det betyder ifølge Mussner, at Israel vil blive frelst ved tro på Kristus og ikke, simpelthen, ved blot at tage del i pagten mellem Gud og Israel som defineret ved Moseloven. Den "kristne" tro på den "kristne" messias fremkaldes af eller gennem Kristi genkomst, når han forkynder evangeliet for Israel på den yderste dag. Ifølge denne forståelse frelses de hedninger, der tror på Kristus, i traditionel forstand på en "kristen" måde (ved at tro på Kristus). Israel, derimod, frelses på en særlig måde eller af en "særlig vej" (= Sonderweg), når Kristus giver dem en sidste chance for at omvende sig til kristendommen.

4. Jf. artiklen af Paula Fredriksen: "Why Should a "Law-Free" Mission Mean a

"Law-Free" Apostle?", JBL 134 (2015), 637-650.

5. Franz Mussner, Traktat über die Juden (München: Kosel 1979).

6. Jf. yderligere Franz Mussner, "Heil für Alle: Der Grundgedanke des Römerbriefs", Kairos 23 (1981), 207-214 (211f.); Die Kraft der Wurzel (Freiburg: Herder 1988), 48ff.. Mussner argumenterer yderligere for sin Sonderweg forståelse ud fra Paulus' egen omvendelse som en typologi eller et paradigme for Israels omvendelse. Ifølge Mussner konverterede Paulus fra jødedommen til kristendommen, og på samme måde vil Israel på den sidste dag omvende sig fra jødedommen (den jødiske religion) til kristendommen. 
Den anden forståelse af to-pagts teologien eller af en Sonderweg vender den første på hovedet. Den anden forståelse af en to-pagts teologi argumenterer for, at Israels frelse fuldstændig forbigår Kristus som frelsesvej - både $\mathrm{i}$ hans første og anden tilsynekomst. Forskere som Krister Stendahl, John Gager, og Lloyd Gaston kan siges at tilslutte sig denne forståelse. ${ }^{7}$ Når det drejer sig om Krister Stendahl, er der ikke meget bevismateriale for, at han tilslutter sig denne forståelse af en to-pagts teologi, men han tages meget ofte til indtægt for en sådan. John Gager er til gengæld ganske udtalt i sin støtte til en to-pagts teologi, men kun i den særlige udformning som er omvendt fra Mussners oprindelige forståelse. John Gager fastholder, at Israel fortsætter med at være Guds udvalgte folk efter Kristi komme til jord, og at Kristus udelukkende fungerer som frelser for hedningerne ikke jøderne. I forlængelse af den gammeltestamentlige pagt mellem Gud og Israel står Israel stadig i et ret forhold til Gud - på trods af Kristi komme til jord - og Israel nyder fortsat en privilegeret position blandt folkeslagene på jorden, fordi Gud er trofast over for sit løfte til Israel, som han lovede at ville være. John Gager overtager E.P. Sanders forståelse af pagtsnomismen ("covenantal nomism") ${ }^{8}$ og han advokerer for en fuldt ud positiv forståelse af jødedommen på Paulus' tid. Dette fører Gager til at hævde, at Paulus aldrig opfordrede jøder til at accepterer Kristus som en frelsende messias, og han fordømte dem heller aldrig for at afstå fra at gøre det. Fordi Israel har stået i et ret pagtsmæssigt forhold til Gud, lang tid før fokus blev rettet mod hedningerne, omvender Gager betydningen af Sonderweg forståelsen fra Mussner: Ifølge Gager var Israels frelse aldrig betvivlet (hvilket ifølge Gager er præcist, hvad Rom 11,26 bekræfter). Det, Paulus forkyndte, var en særlig vej (en Sonderweg) til frelse for hedninger gennem Kristus. " Den "oprindelige" eller "egentlige" vej til frelse var den, hvor Israel forblev trofaste i pagtsrelationen til Gud, og den særlige vej til frelse var for hedninger gennem Kristus. På dette punkt er det passende at tilføje, at ikke alle radikale forskere tilskriver sig denne forståelse af Rom 11,25-26 - fx ikke Mark Nanos. Så selvom to-pagts teologien overordnet set spiller en stor rolle inden for det radikale perspektiv og størstedelen af de radikale forskere forholder sig til den, er det ikke alle, der tilskriver sig den her udfoldede forståelse.

7. Jf. Krister Stendahl, Paul among Jews and Gentiles (Philadelphia: Fortress Press 1976), 4; John Gager, The Origins of Anti-Semitism (Oxford: Oxford University Press 1983); Lloyd Gaston, Paul and the Torah (Eugene: Wipf \& Stock Publishers 1987), 147-150.

8. Ed P. Sanders, Paul and Palestinian Judaism (Minneapolis: Fortress Press 1977), 75.

9. John Gager, Reinventing Paul (Oxford: Oxford University Press 2002), 146. 


\section{Paulus, hedningernes apostel}

Det sidste områder, der i særlig grad definerer det radikalt nye Paulusperspektiv, omhandler den stadige insisteren på, at Paulus (udelukkende og eksklusivt) var hed ningernes apostel. Dermed forstås, at Paulus ikke forkyndte et universelt budskab til hele menneskeheden (både jøder og hedninger), men at han udelukkende og eksklusivt adresserede sit budskab til hedninger. Dette er, hvad Galaterbrevet 2 omhandler i aftalen mellem Paulus og Peter (Peter til jøderne, Paulus til hedningerne), og hvad Paulus eksplicit hævder og understreger i

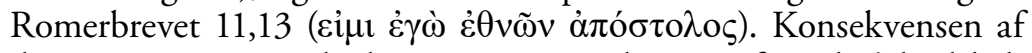
denne insisteren på hedninger som modtagere af Paulus' budskab er, at Paulus administrerede små jødiske grupperinger, der levede en form for jødisk liv udviklet af jøder til trods for det faktum, at dem, der tilsluttede sig disse grupperinger, var og forblev ikke-jøder (altså hedninger). Paulus forblev inden for jødedommen, og han forkyndte en form for jødedom, men det var en jødedom eksklusivt henvendt og udformet til hedninger, hvorfor det ingen relevans havde for jøder. Det betød en jødisk livsform for hedninger, uden at de faktisk blev jøder. Hedningerne skulle ikke blive jøder - de skulle ikke undergå det etniske omvendelsesritual, som omskærelsen betegnede. Alligevel skulle de på en eller anden måde stadig tilpasse sig den mosaiske lov og dens principper, selvom de ikke blev faktiske jøder. Denne pointe er vigtig at understrege, da der er stor forskel på, om man opretholder og følger adfardsmassige retningslinjer, der fungerer inden for et jødisk fællesskab, eller om man undergår en etnisk identitetsforvandling fra ikke-jøde til jøde ved omskærelsen. De radikale forskere hævder, at de hedninger, der kom til tro, ikke skulle undergå en etnisk identitetsforvandling, men de skulle i høj grad opretholde og følge jødisk definerede adfærdsmæssige retningslinjer. Dermed forbliver Paulus og hans menigheder inden for jødedommen til trods for, at den vigtigste etniske identitetsmarkør, omskærelsen, udeblev. Dette svarer til, at Paulus bad sine menighedsmedlemmer om at leve jødiskagtigt uden faktisk at være jøder.

Hvordan kan vi gribe forstålsen af Filipperbrevet an ud fra denne begrebsmæssige ramme?

\section{Radikale læsninger af Filipperbrevet}

Filipperbrevet er ikke et af de populære breve blandt radikale forskere. Der findes endnu ikke en komplet radikal læsning af brevet, hvilket indikerer, at Filipperbrevet ikke står særligt centralt i spørgsmålet om 
et radikalt nyt Paulusperspektiv. Størstedelen af de radikale forskere, der fokuserer på Filipperbrevet, retter opmærksomheden mod Paulus' beskrivelse af sig selv og sin fortid i kapitel 3. Paulus' selvfremstilling indeholder vitale informationer for enhver forsker, der ønsker at undersøge en positiv fremstilling af jødedommen, hvilket fører til, at mange radikale forskere præsenterer lange parafraseringer af Paulus' selvfremstilling. Derudover har i hvert fald en enkelt forsker forsøgt at forstå en positiv fremstilling af jødedommen på Paulus' tid ud fra Paulus' omtale af modstanderne i Fil 3,2. Dette omhandler i særlig grad den radikale pointe, at Paulus udelukkende adresserede sit budskab til hedninger, og i den sammenhæng hverken bagvaskede eller kritiserede nogle jøder eller jødiske traditioner. I forbindelse med omtalen af modstanderne som hunde i Fil 3,2 trækker jeg på en artikel af Mark Nanos fra 2009. Nanos forsøger at underminere den alment udbredte og blandt forskere traditionelle forståelse af "hundene" som en betegnelse for jøder, judaister eller jødiske kristne. I henseende til Paulus' selvfremstilling trækker jeg på Pamela Eisenbaums beskrivelse af Paulus i bogen Paul was not a Christian (2009). ${ }^{10}$

\section{Modstanderne (Fil 3,2)}

I Fil 3,2 advarer Paulus imod hundene, de slette arbejdere og de

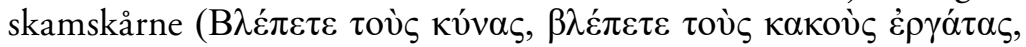

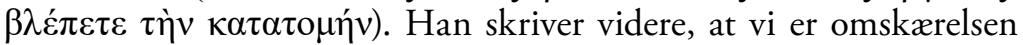

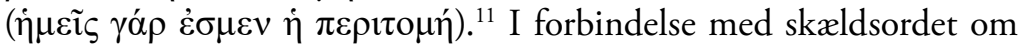
hundene viser forskningshistorien, at forskere traditionelt set har forstået udtrykket således, at Paulus "omvender" eller "tilbagefører" referencepunktet for skældsordet, fordi jøder - tilsyneladende ret

10. Mark Nanos, "Paul's Reversal of Jews Calling Gentiles 'Dogs' (Philippians 3:2): 1600 Years of an Ideological Tale Wagging en Exegetical Dog?", Biblical Interpretation 17 (2009), 448-482. Pamela Eisenbaum, Paul was not a Christian: The Original Message of a Misunderstood Apostle (New York: HarperOne 2009).

11. En radikal læsning af Fil 3,2-3 ville sandsynligvis påpege som en afgørende pointe, at Paulus ikke opstiller en modsætning mellem en "sand" og en "falsk" omskærelse - hvad mange kommentatorer ellers hævder. Paulus fremskriver ingen konkurrence mellem jødedom og Jesustro angående hvilken omskærelse er den sande og hvilken den falske, og hvem der udgør det "sande" Israel. Paulus

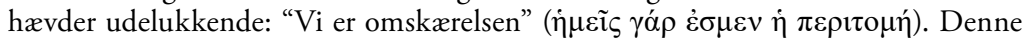
pointering peger i retning af, at Paulus på dette sted $i k k e$ advarer menigheden imod rivaliserende jødiske forkyndere (hvad han tilsyneladende gør i Galaterbrevet). Det viser snarere, at Paulus opridser konceptuelle grænser for menighedens medlemmer mellem jøder og hedninger, dem inden for og dem udenfor. Paulus' hensigt med udtrykket om, at de er omskærelsen, sigter dermed snarere mod at sikre modtagerne af brevet om, at de besidder en position inden for jødedommen som en særlig og tilsidesat gruppe af hedninger, der er forskellig fra de omkringværende og ikkeKristustroende hedninger. 
ofte ifølge kommentatorerne - omtalte hedninger i nedværdigende vendinger som hunde. Paulus skulle så omvende denne praksis i 3,2, så ordet blev anvendt mod dem, der traditionelt set anvendte det. Den nedværdigende anvendelse af øgenavne eller skældsord forstås blandt forskere således, at Paulus' udtrykker en uspecificeret henvisning til hunde (sammen med "slette arbejdere" og "skamskårne") som henvendt til jøder, judaister, jødiske kristne og jødedommens værdier. Mange kommentatorer specificerer, at disse betegnelser kun gælder de jøder, der promoverer deres tro, og endnu mere specifikt de jødiske kristne, der promoverer deres tro over for Kristus-troende ikke-jøder (= hedninger). Kristustroende jøder, der promoverer deres tro omtales ofte som judaister, fordi de anses for at være fortalere for omskærelse af proselytter. ${ }^{12}$ Nedenfor citerer jeg nogle af de kommentatorer, der griber verset an som forklaret. Jeg har tjekket mange kommentarer, og billedet er det samme over en bred kam. Det drejer sig altså om, at kommentatorerne mener, at det var en alment udbredt praksis blandt jøder at omtale hedninger som hunde, og at Paulus så omvender eller tilbagefører denne praksis og i stedet kalder jøder, judaister eller jødiske kristne for hunde.

Gerhard Barth: "'Hund' ist zwar ein geläufiges Schimpfwort, das im Judentum vor allem auf Unwissende, Gottlose und Heiden angewand wird..."13

Markus Bockmuehl: “... the Philippians know perfectly well who is meant by "the dogs": Christian Jews..." 14

Gordon Fee: "[dog is]... against (apparently) Jewish Christians..." "... 'look out for the dogs.' ... Jews, who sometimes used 'dog' to designate Gentiles. Paul uses epithets that turn the tables on them [the Jews], as to what they think themselves to be in contrast to what he thinks." 15

Ben Witherington: "But who are these dogs? Normally, the term "dog", if it came out of the mouth of a Jew, referred to a non-Jew, but not in this case. Here, Paul has reversed the polarity of the term to refer to ... Jewish Christians..." ... "It returns with fierce irony the insult usually addressed to pagans."” 16

12. Jf. Nanos (2009), 449-450.

13. Gerhard Barth, Der Brief an die Philipper (Zürich: Theologisher Verlag 1979), 56.

14. Markus Bockmuehl, A Commentary on the Epistle to the Philippians (London: A\&C Black 1997), 193.

15. Gordon Fee, Paul's Letter to the Philippians (Grand Rapids: Eerdmans 1995), 293-295.

16. Ben Witherington, Paul's Letter to the Philippians - A Socio-Rhetorical Commentary (Grand Rapids: Eerdmans 2011), 181, 188 
Ulrich B. Müller: "Im Judentum werden damit Gottlose und Heiden tituliert... Jedenfalls trifft die Gegner ein geläufiges Wort jüdischer Verachtung gegenüber Heiden." ${ }^{17}$

John Reumann: "3:2 is often said to stem from application of "dogs" by Jews to "non-Jews or lapsed Jews (Mt 7:6; 15:26-27)"... Paul then turns back on Jews or Jewish Christians in 3:2 an epithet they contemptuously used of others." 18

Disse eksempler vidner om en udbredt forskningsmæssig konsensus omkring den forestilling, at jøder omtalte hedninger som hunde, $o g$ at Paulus i Fil 3,2 omvender denne negative praksis. Inden for rammerne af det radikale perspektiv er det meget vanskeligt at acceptere forestillingen om, at Paulus skulle tale nedsættende om jødedommen eller jødiske værdier, fordi han stadig anser sig selv for at være inden for jødedommen (Paul within Judaism). En radikal tilgang til Filipperbrevet vil derfor undersøge, om denne praksis blandt jøder er forstået korrekt, eller om det kan forklares anderledes. Derfor er en mulig radikal tilgang til Filipperbrevet en efterprøvelse af de eksempler, der findes i litteraturen, hvor jøder omtaler hedninger som hunde. I det følgende trækker jeg på Mark Nanos' artikel fra 2009.

\section{Hunde i Det Gamle Testamente}

Hunde anvendes ganske ofte i Det Gamle Testamente på en generelt nedsættende måde. Udtrykket anvendes oftest om modstandere eller rivaler, og det anvendes om syndere, tåber og jøder - inklusiv af jøder om andre med-jøder. ${ }^{19}$ I tilfældet "israelitiske hunde" refererer det til andre israeliter, der ikke opfører sig som israeliter burde opføre sig, ofte politiske rivaler. Der findes faktisk kun ganske få henvisninger til hunde, der kan forstås som omhandlende hedninger. Ikke desto mindre er det ofte et sammensurium af disse referencer, kommentatorerne henviser til.

I 1 Sam 17,43 hvæser Goliat af David og siger: "Tror du, jeg er en hund, siden du kommer mod mig med din stav?" Goliat responderer på Davids tilstedeværelse, fordi David kun er en dreng, og fordi han nærmer sig med en stav, som var han en hyrde. Denne kontekst tydeliggør, at omtalen af Goliat som en hund ikke omhandler Goliat som en hedning per se. Den omhandler snarere Goliats opfattelse af

17. Ulrich B. Müller, Der Brief des Paulus an die Philipper (Leipzig: Evangelisher Verlag 2002 [1993]), 145.

18. John Reumann, Philippians (New Haven: Yale University Press 2008), 461.

19. Jf. 5 Mos 23,19; Dom 7,5; 1 Sam 17,43; 2 Sam 3,8; 9,8; 2 Kong 8,13; Sl 22,16;

59,6, 14; Ordspr 26,11; Es 56,10-11. Jf. også Sir 13,18. 
David som en hyrde, der bekæmper en hund med en stav. Hvis vi læser videre i Første Samuelsbog, underbygges forestillingen om en manglende forbindelse mellem hedninger og hunde. I 1 Sam 24,15 kan vi notere, at David stiller Saul et spørgsmål: "Hvem er det, Israels konge er rykket ud efter? Hvem er det, du forfølger? En død hund, en loppe!" David spørger Saul, om hans jagt efter ham er jagten på en død hund eller en loppe. På baggrund af denne udtalelse står det klart, at David omtaler sig selv som en hund; han henviser ikke til nogen hedning. Dermed er der ingen forbindelse i disse passager mellem hedninger og hunde. Tværtimod udtrykker sproget en metaforisk omtale i nedsættende toner om hunde, der intet har med faste jødiske stereotype forestillinger om hedninger qua hunde at gøre.

Den samme pointe kan anvendes på en yndet reference blandt kommentatorerne om hedningen, Hazael fra Aram. I en samtale med Elisa omtaler Hazael sig selv således: "Hvad er din hund af en tjener, at han skulle kunne udføre så store bedrifter?" (2 Kong 8,7-13) Pointen i beretningen om Elisa og Hazael er dog ikke, at Hazael er hedning, men at han er Arams konge, Ben-Hadads, tjener. Det er derfor, han omtales negativt. 2 Kong 8 kan derfor på ingen måde anvendes som en stereotyp jødisk polemik imod hedninger. Beretningen berettiger simpelt hen ikke en sådan forståelse af anvendelsen af "hund."

Den samme pointe gælder Sl 22, hvor salmisten skriver: "Hunde omgiver mig, en flok af forbrydere står omkring mig; de har gennemboret mine hænder og fødder.” Kommentatorer anvender ofte dette vers i fremskrivningen af en stereotyp jødisk forståelse af hedninger som hunde, men det er langt fra sikkert, at salmen omhandler netop dette. Internt i salmen er der nærmest intet specifikt, der kan anvendes til at identificere modstanderne, der omgiver salmisten. Og i mange af de andre salmer, er der et udtalt fokus på med-israelitter som fjenderne - særligt de salmer, der tilskrives David, da han kæmpede med Saul (Sl 59) og Absalom (2 Sam 16,9). I disse salmer anvendes udtrykkene om hunde og løver metaforisk i forsøget på at kommunikere, hvordan vilddyr angriber salmisten. De anvendes på ingen måde til at identificere en speciel gruppe eller etnicitet som identiske med hunde og løver. Denne omtale af hunde og løver som modstandere er sandsynligvis en henvisning til omkringværende politiske fjender, men ikke hedninger per se. Dermed er der ingen af de traditionelle "beviser," der kan anvendes i forsøget på at fremskrive en almen og udbredt praksis og forståelse blandt jøder om, at hedninger var hunde. Der kan ikke påvises nogen fælles jødisk tradition, hvor jøder kalder hedninger hunde, og dermed er der ingen fælles tradition, Paulus kan omvende. 


\section{Hunde i de gammeltestamentlige pseudepigrafer, $i$ Dødehavsrullerne og hos Filon og Josefus}

Der er ingen forekomster i de gammeltestamentlige pseudepigrafer, der kan anvendes i fremskrivningen af en fælles jødisk praksis for omtalen af hedninger som hunde. Visse kommentatorer henviser alligevel til Enok 89,42-49. Problemet med denne passage er, at den udgør en del af en allegori, hvor et væld af vilde dyr repræsenterer kongeriger, der undertrykker fårene (= Israel). Der er intet i passagen, der retfærdiggør forståelsen af, at hedninger almindeligvis omtales som hunde, fordi de ikke er jøder. Det samme gælder anvendelsen af hunde i Enok 90,4. Enoks bog fungerer dermed heller ikke som et bevis for en alment udbredt praksis. Der er intet i Enok, der vidner om, at jøder almindeligvis kaldte hedninger hunde, og dermed er der ingen tradition, Paulus kan omvende.

Der er kun ganske få henvisninger til hunde i Dødehavsrullerne, og ingen af dem kan anvendes til at hævde, at jøder almindeligvis kaldte hedninger for hunde. Dermed kan henvisninger til Dødehavsrullerne heller ikke anvendes som et "bevis" for denne forståelse. Det samme gælder hos Filon og Josefus, hvor der ikke findes nogle anvendelser af hunde om hedninger per se. ${ }^{20}$ Der er dermed heller ikke noget hos Filon og Josefus, der kan anvendes i fremskrivningen af en alment udbredt jødisk forståelse af hedninger som hunde. Og dermed er der ingen alment udbredt praksis, Paulus kan omvende.

Overordnet set kan vi dermed konkludere, at der ikke findes noget materiale forud for Filipperbrevets affattelse, der opretholder beskyldningen om, at Paulus gjorde brug af typisk jødisk nedsættende sprogbrug om hedninger. De ovenstående eksempler bevidner, at anvendelsen af hund ikke almindeligvis blev brugt af jøder til at fordømme hedninger qua hedninger. Det er simpelthen ikke muligt ud fra disse tekster at sidestille det at være hedning med det at være en hund, selvom størstedelen af kommentatorerne hævder det. ${ }^{21}$ Dermed

20. Jf. Filon Laws 4.91; Vita Contemp 40; Free 89-91; Gaius 139; Josefus Apion 2.85 .

21. Ud over kommentatorerne findes der masser af andet forskningslitteratur, der på samme måde som kommentatorerne hævder, at det var en alment udbredt prak-

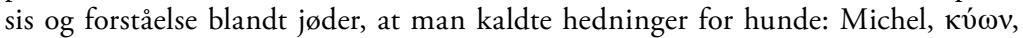
Theological Dictionary of the New Testament (Grand Rapids: Eerdmanns 1965), 3.1101-4; Helmuth Koester, "The Purpose of the Polemic of a Pauline Fragment", NTS 8 (1961-62), 317-32 (319 n7); D.E. Garland, "The Composition and Unity of Philippians: Some Neglected Literary Factors", Novum Testamentum 27 (1985) 141-73 (167 n92; 168); David A. DeSilva, "No Conficence in the Flesh: The Meaning and Function of Philippians 3:2-21", TRINJ 15NS (1994) 27-54 (34); Michael Tellbe, Paul Between Synagogue and State: Christians, Jews, and Civic Authorities in 
bør vi konkludere, at Paulus sandsynligvis hverken kritiserer jøder eller jødiske traditioner i Filipperbrevet, fordi der simpelthen ikke er nogen alment udbredt jødisk tradition, han kan omvende. Det betyder samtidig, at Paulus i Filipperbrevet ikke argumenterer imod rivaliserende jøder, men at han sandsynligvis advarer imod nogle uspecificerede (hedninge-)modstandere fra den filippæiske omverden. Disse modstandere kunne være kynikere på grund af navnet, Paulus anvender (og på grund af andre træk ved brevet), men det kunne også være nogle helt tredje. ${ }^{22}$ Den radikale pointe består dermed i, at Paulus hverken kritiserer jøder eller jødiske traditioner, og hvis man konstruerer sin fortolkning af Filipperbrevet således, så tager man del i en "kristianiserende" og erstatningsteologisk fortolkning af en jødisk tekst. Vi kan muligvis finde støtte for en sådan forståelse i Matt 7 og Mark 7, men disse tekster er skrevet efter Filipperbrevet, og kan dermed ikke anføres som støtte for en alment udbredt jødisk praksis. Derudover tvivler jeg på, at nogen ønsker at argumentere for, at Jesus var ophavsmand til en nedsættende omtale af hedninger som hunde. Dermed kan vi afslutningsvis hævde, at en radikal forståelse af Filipperbrevet påpeger, at Paulus ikke nedgjorde nogen jøder, men at han snarere argumenterer imod lokalt situerede hedenske grupperinger, der skabte problemer for menigheden i Filippi.

\section{Paulus' selvforståelse}

Fra et radikalt perspektiv er Paulus ikke en konvertit. Hans oplevelse på vejen til Damaskus (Acta 9), hvor han har et syn af himlen, forstås ikke som en beretning om Paulus omvendelse. De radikale forstår ikke Paulus som en konvertit fra jødedommen til kristendommen men som en, der er kaldet i forlængelse af de gammeltestamentlige profeter som fx Jeremias (jf. Jer 1:4-5 og Gal 1:15-16). Det betyder, at de radikale lægger større vægt på kontinuiteten i Paulus’ selvforståelse

1 Thessalonians, Romans, and Philippians (Stockholm: Almqvist \& Wiksell 2001) 259-60; A.H. Snyman, "A Rhetorical Analysis of Philippians 3:1-11", Neotestamentica 40 (2006), 259-83 (267-69).

22. Kynikerne praktiserede "fri tale" ( $\pi \alpha \rho \rho \eta \sigma i ́ \alpha)$ (jf. Diogenes Laertius, Lives, 6.69) og Paulus præsenterer sig selv som værende i stand til det samme, eftersom

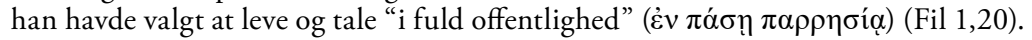
Paulus kan dermed forstås som forsøgende at overgå kynikerne på deres eget område. Han beskriver også sin udholdenhed i forholdet til filipperne ved hjælp af atletisk sprogbrug, hvilket kan forstås som et forsøg på at overgå kynikerne i selvdi-

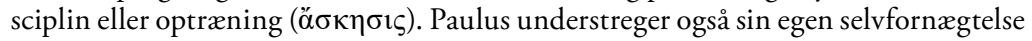
(Fil 3,7-21; 4,5-13), hvilket muligvis er et forsøg på at overtage kynikernes sprog-

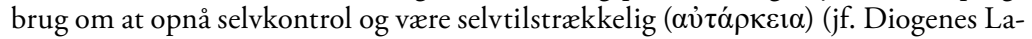
ertius, Lives 6.49, 70-71). Endelig kan Paulus' påstand om, at filippernes borgerskab er i himlen $(3,20)$ være et forsøg på at svare igen på kynikernes påstand om, at de er

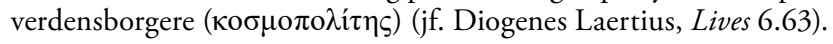


end på diskontinuitet mellem hans liv før og efter kaldelsen. Dette er også gældende for størstedelen af forskere inden for det nye perspektiv, men pointen føres meget mere radikalt igennem blandt radikale forskere.

I Fil 3,2-9 beskriver Paulus sig selv. I 3,5-6 anvender han flere betegnelser om sig selv i forsøget på at understrege sin jødiske identitet. Han beskriver, at han var omskåret på ottendedagen (som 1 Mos 17 foreskriver), han er israelit, hebræer og farisæer. Det faktum, at han understreger at have været farisæer, anses for særligt vigtigt blandt radikale forskere, da det er det eneste sted i hans breve, hvor han anvender denne betegnelse om sig selv. Radikale forskere anvender dette til at pointere, at ikke-radikale forskere bruger dette til at understrege dis-kontinuiteten i Paulus' selvforståelse - altså at han var en ivrig forfølger af kirken, og at han var farisæer, men nu derimod har han vendt sig bort fra disse forhold, der beskriver hans tidligere jødiske identitet. Radikale forskere ville så i stedet fokusere på kontinuiteten mellem hans tidligere liv og det liv, han beskriver for filipperne.

I det følgende vil jeg redegøre for Pamela Eisenbaums forståelse af Paulus' selvbeskrivelse i Filipperbrevet 3. Eisenbaum noterer, at Paulus anvender en præsensform i vers 3: "vi er omskærelsen" (i $\mu \varepsilon \tilde{c} \varsigma$

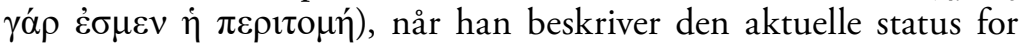
sig selv og sine menighedsmedlemmer (Eisenbaum 2009, 138). Paulus hævder at besidde bestemte kvalifikationer, som han gør fordring på, og at han besidder en privilegeret status på baggrund af sin jødiske herkomst, sin hengivenhed til den jødiske tradition og sit kendskab til loven. Med den mulige undtagelse af farisæer så fremstår alle disse beskrivelser som elementer, der beskriver Paulus på affattelsestidspunktet for brevet. Dermed karakteriserer de hans aktuelle og faktiske liv, og er ikke blot beskrivelser af hans tidligere liv.

Den samme pointe gør sig gældende for Paulus' beskrivelse af sig selv i andre af hans breve. I Romerbrevet 11,1 anvender Paulus også en præsensform: "Jeg er jo også selv israelit, af Abrahams slægt, af

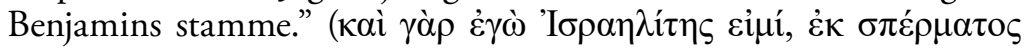

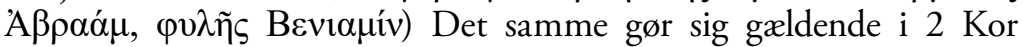
11,22: "Er de hebræere? Det er jeg også! Er de israelitter? Det er jeg

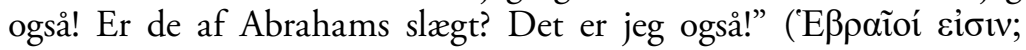

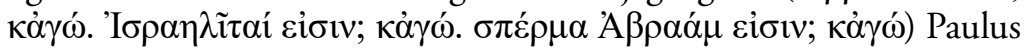
understreger dermed, at han aktuelt er en hebræer; han er israelit; han er en efterkommer af Abraham. Alle disse beskrivelser er ikke mindre sande om ham som en efterfølger af Kristus, end de var for hans møde med Kristus. Dermed må vi forudsætte en fundamental kontinuitet i Paulus' liv i forhold til, hvordan han forstår sig selv før og efter sit møde med Kristus. Han påpeger også selv eksplicit i Galaterbrevet 2,15 sin 
faktiske jødiske identitet: "Vi er jøder af fødsel, ikke syndere af hedensk

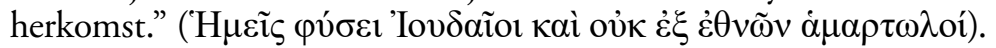

I forsøget på at fremskrive denne kontinuitet i Paulus' liv vender Eisenbaum sig til spørgsmålet om Paulus som farisæer. Eisenbaum hævder, at Paulus' anvendelse af farisæer ikke skal forstås som en beskrivelse af hans tidligere selvidentitet i modsætning til en ny og anderledes selvforståelse. Ifølge Eisenbaum anvender Paulus snarere denne betegnelse i forsøget på at forsikre filipperne om, at han er en yderst kapabel fortolker af loven i kraft af, at han har studeret hos farisæerne. Paulus' anvendelse af farisæer fungerer dermed som en del af hans aktuelle selvidentitet. Han forstår sandsynligvis sig selv som farisæer i den forstand, at denne betegnelse repræsenterer en konstituerende del af hans aktuelle religiøse identitet, selvom han måske tilskriver forståelsen af sig selv som israelit eller efterkommer af Abraham mere værdi. Men hovedpointen ændrer sig ikke af den grund: Paulus anvender ikke betegnelsen, farisæer, om sig selv for at symbolisere den religiøse modsætning til at være "i Kristus" (139). Eisenbaum udfolder yderligere denne pointe ved at sammenligne Paulus' anvendelse af farisæer med en tidligere elev på en fin skole som Harvard eller Yale. Eisenbaum foreslår, at Paulus måske anvender betegnelsen farisæer om sig selv for at fremmane forestillingen af noget som Harvard eller det at være en "Harvardian." Og selvom det er en tidligere forbindelse med dette Paulus påberåber sig, så kan det stadig fungere som en passende måde at beskrive et faktisk aspekt af hans identitet på. Når det kommer til forståelsen af loven, så signalerer Paulus med anvendelsen af farisæer, at han har studeret med de bedste på den fineste skole. På denne måde forsøger Eisenbaum at løsne og opbløde forståelsen af farisæer som noget, der tilhørte Paulus' "gamle" og tidligere liv.

Eisenbaum zoomer derefter ud og forsøger at præsentere en bredere forståelse af passagens retoriske strategi og indre logik. Hun noterer, at det er vigtigt at få med i forståelsen af passagen, at den retoriske styrke i Paulus' argument afhænger af, at man anerkender identitetsmarkørerne som statusindikatorer - ikke noget, der indikerer skam. Hvis Paulus virkelig er reel i sin udtalelse om, at han anser alle disse jødiske privilegier og akkreditiver for at være tab, så må det betyde, at de almindeligvis tæller som værdifulde for modtagerne af brevet. Det betyder, at Paulus ikke anser sit tidligere liv som et liv levet i synd og fornedrelse, da fravalget af et sådant liv ikke ville være noget man anså for at være tab. Hvis en person opgav et liv i synd og fornedrelse, ville det blive forstået som en fordel eller en fortjeneste at opgive et sådant liv. Dermed må passagens logik forstås omvendt: Hvis Paulus vitterligt opgav dette serligt jødiske 
liv, så må modtagerne af brevet have anset et sådant liv for at være prestigefyldt, højt anset og noget, man burde stræbe efter at opnå. Det at være israelit, en efterkommer af Abraham og at have opnået farisæisk træning i loven må anses for at være yderst værdifulde ting, som modtagerne af brevet sikkert gerne har villet hævde om sig selv. Det kan ikke forstås som skamfulde ting, men må i stedet forstås som æresbevisninger. Det er statussymboler og særligt anerkendte goder, der er attraktive, ønskværdige og ærefulde - i hvert fald for jøder. Dette er i særlig grad noget, folk ville bryste sig af og ikke noget, der forårsager forlegenhed. ${ }^{23}$ Logikken i Paulus' argument bygger dermed på, at han ikke længere værdsætter sådanne fordringer på ære og status, fordi de blegner i sammenligning med det at være en efterfølger af Kristus. Og hovedpointen omkring det nye liv i Kristus er dermed, at det ligger i forlangelse af det netop beskrevne liv. Der er ikke tale om en ny religion eller en ny sfære sui generis. Der er i stedet tale om et liv i kontinuitet med de æresbevisninger, der fandtes inden for jødedommen. Oprindelsen for det fællesskab, Paulus deltog i, var jødisk; de fleste andre Kristus-efterfølgere i denne periode var jødiske; og den person, de holdt i ære, var israelit og jøde. Dermed har det primære referenceområde for status og ære sandsynligvis været jødisk. Og det er derfor, Paulus nærmest udelukkende anvender jødiske statussymboler til at beskrive sig selv med: Han var omskåret, hebræer, moralsk uantastelig ifølge loven, og højt uddannet i skriften. Dermed bør vi forstå, at Paulus aldrig forkastede sin jødiske identitet. Der findes ingen beviser for, at Paulus' jødiske identitet var mindre solid eller intakt efter hans møde med den opstandne Kristus, end den var før dette møde.

\section{Konsekvenserne af en radikal forståelse af Filipperbrevet}

Til slut vil jeg drage konsekvenserne af de anvendte indsigter ud fra et radikalt perspektiv for en læsning af Filipperbrevet. Først adresserer jeg spørgsmålet om modstanderne og hundene, og derefter spørgsmålet om Paulus' selvforståelse.

Hvis vi forsøger at forstå Filipperbrevet inden for rammerne af det radikalt nye Paulusperspektiv, hvor Paulus ikke rakker jødedommen eller jødiske traditioner ned, så argumenterer han ikke imod jødiske rivaler i Fil 3,2, når han kalder dem hunde. Der findes simpelthen ingen

23. I denne forstand giver det god mening at sammenligne forståelsen i Filipperbrevet med den indbildske hedning i Rom 2,17, der "kalder sig jøde" og bryster sig af at være oplært i loven og en, der kender Gud. 
berettiget forudgående tradition, der kan retfærdiggøre påstanden om, at Paulus omvender traditionel jødisk polemik mod hedninger som værende hunde. Det betyder, at modstanderne i Filippi ikke kan forstås som jøder, judaister eller jødiske kristne. Dette udgangspunkt ændrer den historiske og kontekstuelle ramme for vores forståelse af Filipperbrevet. Vi må dermed forsøge at om- og genskrive konteksten for situationen i Filippi. Hvis Paulus ikke advarer filipperne imod jøder, judaister eller jødiske kristne, så må vi spørge, hvem han så advarer imod, og hvad det fortæller os om situationen for menigheden i Filippi og historien bag brevet. Og blot for at skitsere nogle få muligheder, så bør vi ikke anvende situationen fra Galaterbrevet til bedre at forstå situationen i Filippi. I stedet bør vi prøve at fokusere på den hedningemæssigt baserede sammensætning af menigheden i Filippi, og den potentielle hedningemæssigt baserede modstand mod Paulus mission i Filippi. Filipperne oplevede sandsynligvis ingen problemer med jøder, men blev derimod nok udfordret i kraft af deres tidligere liv som hedninger, og den omkringværende hedenske situation i byen. Filipperbrevet udgør dermed et forsøg fra Paulus' side på at trække konceptuelle og virtuelle grænser mellem menigheden i Filippi og dem "uden for", hvor menigheden i Filippi skulle forstå sig selv som situeret inden for jødedommen og dermed som forskellig fra alle de andre hedninger uden for. Det grænseskel, Paulus forstærker med sit brev, er mellem jødedommen (dem inden for inklusiv menigheden i Filippi) og "alle de andre" (hedningerne eller nationerne). Denne konklusion fører os videre over i den anden pointe, der omhandler Paulus's selvforståelse.

Referencerammen for Paulus' liv og identitet må stadig forstås som jødedommen, ikke kristendommen. Paulus anser stadig sig selv som værende inden for jødedommen, selv hvis hans møde med Kristus havde vidtrækkende konsekvenser for hans liv som en ivrig og gudfrygtig farisæisk jøde. Hans møde med Kristus afbrød eller forstyrrede ikke hans jødiske identitet, men fokuserede den snarere $i$ en meget mere snæver retning imod inklusionen af hedningerne i Israel i forlængelse af Es 60. I denne forstand forstod Paulus sig selv som en del af den gammeltestamentlige profetiske tradition ligesom fx Jeremias. En sådan forståelse af Paulus kan potentielt og indirekte være med til at kaste lys over en to-pagts teologi og Paulus' udsagn i Rom 11,26 om, at hele Israel skal frelses, selvom dette ikke er blevet udfoldet her. Paulus fornægtede aldrig sin jødiske baggrund og tradition, og han konverterede heller aldrig til en anden religion. Han forblev trofast inden for den pagt, Gud havde oprettet mellem sig selv og Israel, selvom hans egen særlige mission fokuserede på inklusionen af hedningerne i dette pagtsfællesskab mellem Gud og Israel. 